КОМПЕТЕНТНІСНИЙ ПІДХІД ЩОДО ПІДГОТОВКИ МАГІСТРІВ 3 ЕЛЕКТРИЧНОЇ ІНЖЕНЕРІЇ В УМОВАХ МАСОВИХ ВІДКРИТИХ ДИСТАНЦІЙНИХ КУРСІВ ПІД ЧАС ВИВЧЕННЯ ЗАГАЛЬНОТЕХНІЧНИХ ДИСЦИПЛІН В АГРАРНИХ УНІВЕРСИТЕТАХ

\title{
COMPETENCE APPROACH TO TRAINING MASTER OF ELECTRICAL ENGINEERING IN THE MASS OPEN DISTANCE COURSES AT STUDIED GENERAL TECHNICAL DISCIPLINE IN AGRICULTURAL UNIVERSITY AGRICULTURAL UNIVERSITY
}

УДК 378.14

DOI https://doi.org/10.32843/2663-

6085/2020/30-1.2

\section{Бацуровська І.В.,}

докт. пед. наук, доцент, доцент каседри електроенергетики, електротехніки та електромеханіки Миколаївського національного аграрного університету

\section{Доценко Н.А.,}

докт. пед. наук, доцент,

доцент кафедри загальнотехнічних дисциплін

Миколаївського національного аграрного університету

Горбенко О.А.,

канд. техн. наук, доцент,

доцент кафедри агроінженерії Миколаївського національного аграрного університету

Кім H.I., канд. техн. наук, асистент кафедри агроінженерії Миколаївського національного аграрного університету у статті описано компетентнісний підхід щодо підготовки магістрів з електричної інженерії в умовах масових відкритих дистанційних курсів при вивченні загально-технічних дисциплін в аграрних університетах. Визначено, що професійна компетентність $\epsilon$ засобом пристосування до наукового середовища, оскільки наука й освіта творять людину відповідно до свого образу та подоби, визначаючи ії інтереси, переконання, смаки, прагнення, бажання; формують загальні інтереси, подібності в індивідів, які займаються однією справою.

Компетентність магістра з електричноі інженерії можна трактувати як підготовленість і здатність суб'єкта праці до виконання завдань і обов'язків на займаній посаді, а також як ставлення до успішної профресійної діяльності, усвідомлення ії значення і певних специфрічних задач в сукупності з усіма знаннями і навичками, які використовуються при ії здійсненні. Зазначено, що компетентність в області науки можна трактувати як інтеграцію накопиченого досвіду й отриманих знань, що дозволяють людині швидко вирішувати поставлені завдання у дослідницькій та науковій діяльності.

Визначено основні елементи компетентності як складного утворення. Доведено, що реалізація компетентнісного підходу здійснюватиметься за рахунок оновлення навчально-методичного забезпечення освітнього процесу магістрантів з електричної інженерії, тобто створення сучасного електронного контенту, єдиної системи освітнього процесу, наукової діяльності та обміну досвідом на світовому рівні. Зазначено, що компетентнісний підхід щодо профресійної підготовки магістрів з електричної інженерії в умовах масових відкритих дистанційних курсів при вивченні загально-технічних дисциплін в аграрних університетах реалізується за рахунок сучасних навчальних засобів, які виконують інфрормаційну, мотиваційну і розвивальну фуункції.

Реалізація компетентнісного підходу в підготовці магістрів з електричної інженерії буде успішною за умови забезпечення усіх складників навчального процесу: чіткого визначення цілей навчання, добору відповідного змісту навчання, оновлення навчальнометодичного забезпечення, добору ефективних методів, прийомів навчання і форм організації просресійної діяльності, відповідної профресійної підготовки.

Ключові слова: компетентнісний підхід, підготовка магістрів з електричної інженерії, масові відкриті дистанційні курси, вивчення загально-технічних дисциплін в аграрних універсumemax.

The article describes the competence approach to the training of masters in electrical engineering in the conditions of mass open distance courses in the study of general technical disciplines in agricultural universities. It is determined that professional competenceis ameans of adaptation to the scientific environment, as science and education create a person in accordance with their image and likeness, determining its interests, beliefs, tastes, aspirations, desires; form common interests, similarities in individuals engaged in one business.

The competence of the master of electrical engineering can be interpreted as the readiness and ability of the subject to perform tasks and responsibilities in the position, as well as the attitude to successful professional activity, awareness of its importance and certain specific tasks in conjunction with all knowledge and skills used in its implementation. It is noted that competence in the field of science can be interpreted as the integration of experience and knowledge that allows a person to quickly solve problems in research and scientific activities.

The main elements of competence as a complex formation are determined. It is proved that the implementation of the competency approach will be carried out by updating the educational and methodological support of the educational process of undergraduates in electrical engineering, ie the creation of modern electronic content, a unified system of educational process, research and exchange of experience worldwide. It is noted that the competence approach to the training of masters in electrical engineering in the conditions of mass open distance courses in the study of general technical disciplines in agricultural universities is implemented through modern teaching aids that perform informational, motivational and developmental functions. Implementation of the competency approach in the preparation of masters in electrical engineering will be successful provided that all components of the educational process, namely: clear definition of learning objectives, selection of appropriate learning content, updating educational and methodological support, selection of effective methods, teaching methods and forms of professional activity, appropriate training.

Key words: competence approach, training of masters in electrical engineering, mass open distance courses, study of general technical disciplines in agricultural universities.
Постановка проблеми в загальному вигляді. В контексті сучасних інноваційних змін аграрної освіти з'явилася нагальна потреба суспільства у творчих і обдарованих фрахівцях, здатних до життєвого самовизначення. Новітня орілософрія освіти спрямовує навчально-виховний 
процес магістеріуму в аграрному університеті на формування сучасних професійних компетентностей особистості, розкриття потенційних можливостей і здібностей магістрантів, забезпечення оптимальних умов для їх життєвої самореалізації. В контексті зазначеного необхідно підкреслити, що компетентнісний підхід щодо підготовки магістрів $з$ електричної інженерії в умовах масових відкритих дистанційних курсів застосовується при вивченні загально-технічних дисциплін в аграрних університетах.

Аналіз останніх досліджень і публікацій. Загальним питанням щодо методологічних основ компетентнісного підходу присвячували свої роботи М.Ф. Степко, Я.Я. Болюбаш, В.Д. Шинкарук, В.Г. Кремінь, Дж. Равен, А.В. Хуторськой. У своїх дослідженнях І.І. Драч розглядав компетентнісний підхід як ключовий методологічний інструмент підготовки майбутніх фрахівців. Проблеми професійної освіти з позицій компетентнісного підходу досліджували О.А. Дубасенюк, Т.В. Семенюк та О.Є. Антонова. Г.В. Кашкарьов і В.В. Химинець досліджували теоретичні та практичні аспекти компетентнісного підходу до підготовки фрахівців. Однак питання щодо особливостей компетентнісного підходу щодо підготовки магістрів з електричної інженерії в умовах масових відкритих дистанційних курсів при вивченні загально-технічних дисциплін в аграрних університетах залишаються малодослідженими.

Метою статті $€$ окреслити основні принципи компетентнісного підходу щодо підготовки магістрів з електричної інженерії в умовах масових відкритих дистанційних курсів при вивченні загальнотехнічних дисциплін в аграрних університетах.

Виклад основного матеріалу. Однією з найважливіших особливостей підготовки магістра 3 електричної інженерії $€$ зростання значення його компетентності. Дослідник I.І. Драч [6] під компетентністю розуміє спеціальну здатність людини, необхідну для виконання конкретної дії в конкретній предметній області, що включає вузькоспеціальні знання, навички, способи мислення і готовність нести відповідальність за свої дії.

На думку дослідника В.В. Химинця [13], компетентністю $є$ системна єдність, яка інтегрує особистісні, предметні й інструментальні особливості та засоби. Дослідник вважає, що компетентність - це не просто володіння знаннями, а постійне прагнення до їх оновлення та використання в конкретних умовах, тобто володіння оперативними і мобільними знаннями; це гнучкість і критичність мислення, що припускає здатність вибирати найбільш оптимальні та ефективні рішення і відкидати помилкові.

У своїх працях закордонні вчені Дж. Равен [12], К. Крістенсен [1] і Д. Корнер [2] зазначають, що компетентність характеризує суб'єкта діяльності й означає володіння відповідними знаннями та здібностями, які дозволяють людині обґрунтовано судити про певну сореру діяльності й есрективно в ній діяти.

Погоджуючись із думкою вітчизняних учених, зокрема В.Г. Кременя [5], І.І. Драча [6], Г.В. Кашкарьова [10], зазначимо, що компетентність, яка спрямована на професійну діяльність, є здатністю застосовувати свої знання та вміння в науковій і дослідницькій практиці, використовуючи усі свої розумові, психологічні й навіть фрізичні можливості. Вона включає такі складники:

- вміння оцінювати результати своєї профресійної та наукової праці, здатність до самостійного набуття нових знань і вмінь;

- спеціальну компетентність - підготовленість до самостійного виконання професійно-виробничих завдань;

- соціальну компетентність - здатність до групової та колективної діяльності й співпраці 3 іншими працівниками, готовність до прийняття на себе відповідальності за результати праці [3].

У своїй монографії О.А. Дубасенюк [7] зазначає, що компетентність $€$ властивістю особистості, яка забезпечує високий рівень саморозвитку та наукового самовдосконалення. Профресійно компетентність магістра 3 електричної інженерії $€$ властивістю його особистості, яка забезпечує високий рівень саморозвитку та наукового самовдосконалення в науці й освіті.

У контексті здійснення наукового пошуку за відповідним напрямом дослідження професійна компетентність $€$ засобом пристосування до наукового середовища, оскільки наука й освіта творять людину відповідно до свого образу та подоби, визначаючи іï інтереси, переконання, смаки, прагнення, бажання; фрормують загальні інтереси, подібності в індивідів, які займаються однією справою [4].

Г.В. Кашкарьов [10] визначає компетентність фрахівця як систематизовану сукупність знань, високих моральних норм і професійного кодексу. В рамках профресійної стратифрікації суспільства компетентність можна розглядати як професійне покликання науковця, професійний обов'язок, який формується в єдності стилю життя, профресії та освіти. Згідно з позиціями А.В. Хуторського [15], компетентність - це якість фрахівця, яка допомагає йому ефективно вирішувати практичні завдання стосовно власної соціалізації, сприяє забезпеченню внутрішніх умов діяльнісної інтеграції особистості фрахівця в суспільство за рахунок розвитку ціннісних орієнтацій, формування практичних умінь діяльнісної соціально-бажаної самореалізації.

Компетентність магістра з електричної інженерії можна трактувати як підготовленість і здатність суб'єкта праці до виконання завдань і обов'язків на 
займаній посаді, а також як ставлення до успішної професійної діяльності, усвідомлення їі значення і певних специфічних задач в сукупності з усіма знаннями і навичками, які використовуються при її здійсненні. Компетентність в області науки можна трактувати як інтеграцію накопиченого досвіду й отриманих знань, які дозволяють людині швидко вирішувати поставлені завдання у дослідницькій та науковій діяльності.

Автори монографрії О.А. Дубасенюк, Т.В. Семенюк та О.Є. Антонова [8] зазначають, що компетентність $€$ складним утворенням. До її основних елементів вони відносять такі складники:

1) компетентність у галузі фрахових предметів;

2) соціально-психологічну компетентність у галузі процесів спілкування;

3) диореренціально-психологічну компетентність у сфері мотивації, здібностей і спрямованості;

4) аутопсихологічну компетентність у сорері достоїнств і недоліків власної діяльності та особистості, оскільки зріла сфрормована особистість профресійна необхідність.

А.В. Хуторськой [14] зазначає, що компетентнісний підхід є одним зі способів реалізації концепцій розвивальної та особистісно-зорієнтованої освіти. На думку вченого, такий підхід базується на засобах змісту освіти, в основу якого покладено такі компоненти як знання, вміння, досвід творчої діяльності, досвід реалізації емоційно-ціннісних ставлень.

Поняття «компетентнісний підхід» можна розуміти як спрямованість освітнього процесу на формування та розвиток ключових і предметних компетентностей особистості. Компетентнісний підхід скеровує освітньо-науковий процес на фрормування певного набору компетентностей, якими мають оволодіти магістранти з електричної інженерії під час навчання в магістратурі. При цьому традиційна система освіти акцентувала основні зусилля на набутті знань, умінь і навичок, що догматично абсолютизувало знання і сформувало знаннєвий підхід до професійної підготовки магістрів з електричної інженерії.

Базуючись на позиціях законодавства про інтелектуальну діяльність [9] та відповідно до Концепції організації підготовки магістрів [11], компетентнісний підхід ставить на перше місце не поінорормованість магістра, а вміння розв'язувати наукові проблеми, які виникають у пізнавальній, технологічній і освітній діяльностях, у сорерах етичних, соціальних, правових, професійних, особистих взаємовідносин. 3 огляду на це зазначений підхід передбачає такий вид змісту освіти, який не зводиться до знаннєво-орієнтованого компоненту, а передбачає цілісний обмін досвідом вирішення профресійних проблем, виконання ключових функцій, соціальних ролей, компетенцій.
Реалізація компетентнісного підходу здійснюватиметься за рахунок оновлення навчально-методичного забезпечення освітнього процесу магістрантів з електричної інженерії, тобто створення сучасного електронного контенту, єдиної системи освітнього процесу, наукової діяльності та обміну досвідом на світовому рівні. Важливим фрактором щодо реалізації зазначеного підходу за рахунок оновлення навчально-методичного забезпечення $€$ фрункції, які виконують сучасні комп'ютернопланшетні засоби.

Компетентнісний підхід щодо професійної підготовки магістрів 3 електричної інженерії в умовах масових відкритих дистанційних курсів при вивченні загально-технічних дисциплін в аграрних університетах реалізується за рахунок сучасних навчальних засобів, які виконують інформаційну, мотиваційну і розвивальну функції. Реалізація компетентнісного підходу в підготовці магістрів з електричної інженерії буде успішною за умови забезпечення усіх складників навчального процесу: чіткого визначення цілей навчання, добору відповідного змісту навчання, оновлення навчально-методичного забезпечення, добору ефективних методів, прийомів навчання і фрорм організації професійної діяльності, відповідної профресійної підготовки.

Висновки. Компетентнісний підхід щодо підготовки магістрів 3 електричної інженерії в умовах масових відкритих дистанційних курсів при вивченні загально-технічних дисциплін в аграрних університетах зміщує акценти 3 процесу накопичення нормативно визначених знань, умінь і навичок до площини формування й розвитку здатності практично діяти в області науки і творчо застосовувати набутий освітній досвід у різних ситуаціях. Змінюється й модель поведінки майбутнього магістра з електричної інженерії - від пасивного засвоєння знань до дослідницько-активної, самостійної та самоосвітньої діяльності. Процес учіння наповнюється розвивальною функцією, яка стає інтегрованою характеристикою навчання. Така характеристика має сорормуватися у процесі навчання і включати знання, вміння, навички, ставлення, досвід діяльності й поведінкові моделі особистості.

\section{БІБЛІОГРАФІЧНИЙ СПИСОК:}

1. Christensen C. 2003. The innovator's solution: creating and sustaining successful growth. Harvard Business Press.

2. Cormier Dave. The CCK08: MOOC - Connectivism course, 1/4 way. URL: http://davecormier.com/edblog/ 2008/10/02/the-cck08-mooc-connectivismcourse-14-way [Last accessed: 02.10.10].

3. Бацуровська І.В., Самойленко О.М., Андрющенко Я.Е. Компетентністно орієнтоване середовище як засіб підготовки здобувача вищої освіти. Матеріали Причорноморської регіональної науковопрактичної конфреренції професорсько-викладацького складу «Розвиток українського села - основа 
аграрної ресрорми України» 25-27 квітня 2018 року. Миколаїв : МНАУ, с. 43-48.

4. Бацуровська І.В., Самойленко О.М., Ручинська Н.С. Методика реалізації компетентнісного підходу до навчання здобувачів вищої освіти в умовах єдиного інорормаційно-освітнього середовища. Від знаннєвої парадигми до компетентнісної: реалії, перспективи : матеріали Всеукраїнської науковопрактичної конференції 3 міжнародною участю (27 жовтня 2017 року, м. Херсон) / За ред. Г.С. Юзбашевої. Херсон : КВНЗ «Херсонська академія неперервної освіти», с. 188-192.

5. Вища освіта України і Болонський процес : навчальний посібник / Степко М.Ф., Болюбаш Я.Я., Шинкарук В.Д. та інші; за ред. В.Г. Кременя. Київ : Освіта, 2004. С. 144.

6. Драч І.І. Компетентнісний підхід як ключовий методологічний інструмент підготовки майбутніх викладачів вищої школи. Теорія та методика управління освітою : електронне наукове фрахове видання / гол. ред. В.В. Олійник; ДВНЗ «Університет менеджменту освіти» АПН України. 2011. № 7. URL: http:// tme.umo.edu.ua/ [дата звернення: 11.05.15].

7. Дубасенюк О.A. Професійна педагогічна освіта: компетентнісний підхід : [монографрія]. Житомир : Житомир. держ. ун-т ім. І. Франка. С. 302.

8. Дубасенюк О.А., Семенюк Т.В., Антонова О.Є. Профресійна підготовка майбутнього вчителя до педагогічної діяльності : [монограсрія]. Житомир : Житомир. держ. пед. ун-т. С. 53.

9. Законодавство про інтелектуальну діяльність : збірник нормативних актів. 2000. Київ : Юрінком Інтер.

10. Кашкарьов Г.В. Теоретичні та практичні аспекти компетентнісного підходу до підготовки вчителів правознавства : [монографрія]. Донецьк : Ландон-XXI. С. 113.

11. Про Концепцію організації підготовки магістрів в Україні : наказ MOH № 99 від 10.02.2010. URL: http://osvita.ua/legislation/Vishya_osvita/7094/] [дата звернення: 29.01.2016].

12. Равен Дж. Педагогическое тестирование: проблемы, заблуждения, перспективы. Пер. с англ. Москва : Когито-Центр. С. 37.

13. Химинець В.В. Компетентнісний підхід до профресійного розвитку вчителя. Закарпатський інститут післядипломної педагогічної освіти [online]. Режим доступу: http://zakinppo.org.ua/2010-01-18-13-4415/233-2010-08-25-07-10-49 [дата звернення: 23.11.2012].

14. Хуторской А.В. Педагогическая инноватика: методология, теория, практика : научное издание. Москва : Изд-во УНЦ ДО. С. 42.

15. Хуторской А.В. Ключевые компетенции и образовательные стандарты [online]. Режим доступу: http://www.eidos.ru/journal/2002/0423.htm [дата звернення: 23.11.2012]. 